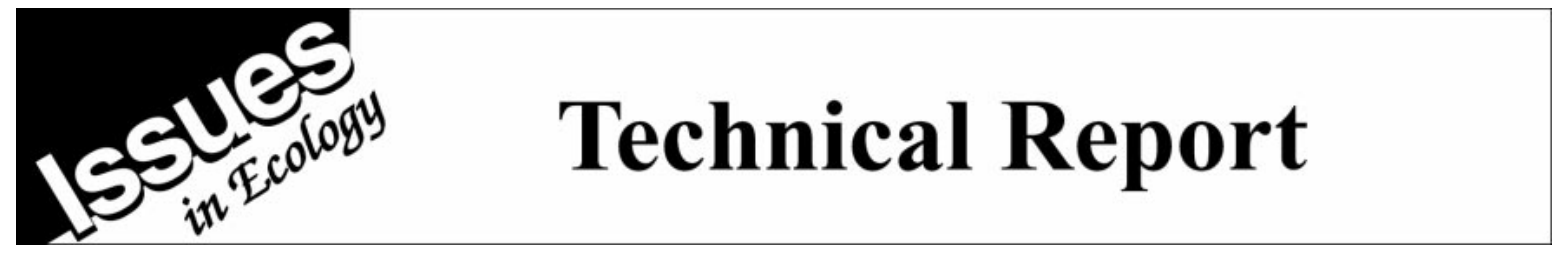

Ecological Applications, 8(3), 1998, pp. 559-568

(C) 1998 by the Ecological Society of America

\title{
NONPOINT POLLUTION OF SURFACE WATERS WITH PHOSPHORUS AND NITROGEN
}

\author{
S. R. Carpenter, ${ }^{1}$ N. F. Caraco,${ }^{2}$ D. L. Correll,${ }^{3}$ R. W. Howarth, ${ }^{4}$ A. N. Sharpley, ${ }^{5}$ And V. H. Smith ${ }^{6}$ \\ ${ }^{1}$ Center for Limnology, 680 North Park Street, University of Wisconsin, Madison, Wisconsin 53706 USA \\ ${ }^{2}$ Institute of Ecosystem Studies, Box AB Route 44A, Millbrook, New York 12545 USA \\ ${ }^{3}$ Smithsonian Environmental Research Center, P.O. Box 28, Edgewater Maryland 21037 USA \\ ${ }^{4}$ Section of Ecology and Systematics, Cornell University, Ithaca, New York 14853 USA \\ ${ }^{5}$ USDA-ARS, Pasture Systems and Watershed Management Research Laboratory, Curtin Road, \\ University Park, Pennsylvania 16802 USA \\ ${ }^{6}$ Department of Systematics and Ecology, 6007 Haworth Hall, University of Kansas, Lawrence, Kansas 66045 USA
}

Abstract. Agriculture and urban activities are major sources of phosphorus and nitrogen to aquatic ecosystems. Atmospheric deposition further contributes as a source of N. These nonpoint inputs of nutrients are difficult to measure and regulate because they derive from activities dispersed over wide areas of land and are variable in time due to effects of weather. In aquatic ecosystems, these nutrients cause diverse problems such as toxic algal blooms, loss of oxygen, fish kills, loss of biodiversity (including species important for commerce and recreation), loss of aquatic plant beds and coral reefs, and other problems. Nutrient enrichment seriously degrades aquatic ecosystems and impairs the use of water for drinking, industry, agriculture, recreation, and other purposes.

Based on our review of the scientific literature, we are certain that (1) eutrophication is a widespread problem in rivers, lakes, estuaries, and coastal oceans, caused by overenrichment with $\mathrm{P}$ and $\mathrm{N}$; (2) nonpoint pollution, a major source of $\mathrm{P}$ and $\mathrm{N}$ to surface waters of the United States, results primarily from agriculture and urban activity, including industry; (3) inputs of $\mathrm{P}$ and $\mathrm{N}$ to agriculture in the form of fertilizers exceed outputs in produce in the United States and many other nations; (4) nutrient flows to aquatic ecosystems are directly related to animal stocking densities, and under high livestock densities, manure production exceeds the needs of crops to which the manure is applied; (5) excess fertilization and manure production cause a $\mathrm{P}$ surplus to accumulate in soil, some of which is transported to aquatic ecosystems; and (6) excess fertilization and manure production on agricultural lands create surplus $\mathrm{N}$, which is mobile in many soils and often leaches to downstream aquatic ecosystems, and which can also volatilize to the atmosphere, redepositing elsewhere and eventually reaching aquatic ecosystems.

If current practices continue, nonpoint pollution of surface waters is virtually certain to increase in the future. Such an outcome is not inevitable, however, because a number of technologies, land use practices, and conservation measures are capable of decreasing the flow of nonpoint $\mathrm{P}$ and $\mathrm{N}$ into surface waters.

From our review of the available scientific information, we are confident that: (1) nonpoint pollution of surface waters with $\mathrm{P}$ and $\mathrm{N}$ could be reduced by reducing surplus nutrient flows in agricultural systems and processes, reducing agricultural and urban runoff by diverse methods, and reducing $\mathrm{N}$ emissions from fossil fuel burning; and (2) eutrophication can be reversed by decreasing input rates of $\mathrm{P}$ and $\mathrm{N}$ to aquatic ecosystems, but rates of recovery are highly variable among water bodies. Often, the eutrophic state is persistent, and recovery is slow.

Key words: agriculture; estuary; eutrophication; lake; nitrogen; nonpoint pollution; phosphorus; river; runoff; stream.

Manuscript received 15 December 1997; accepted 15 January 1998. Reprints of this 10-page report are available for $\$ 1.50$ each. Prepayment is required. Order reprints from the Ecological Society of America. Attention: Reprint Department, 2010 Massachusetts Avenue, NW, Suite 400, Washington, D.C. 20036 


\section{INTRODUCTION}

People are attracted to lakes, rivers, and coastlines for diverse reasons. Clean water is a crucial resource for drinking, irrigation, industry, transportation, recreation, fishing, hunting, support of biodiversity, and sheer esthetic enjoyment. Throughout human history, water has been used to wash away and dilute pollutants. Pollutant inputs have increased in recent decades and have degraded water quality of many rivers, lakes, and coastal oceans. Degradation of these vital water resources can be measured as the loss of natural systems, their component species, and the amenities that they provide (U.S. EPA 1996, Postel and Carpenter 1997). Water shortages are increasingly common and likely to become more severe in the future (Postel et al. 1996, Postel 1997). Water shortage and poor water quality are linked, because contamination reduces the supply of water and increases the costs of treating water for use. Preventing pollution is among the most cost-effective means of increasing water supplies.

Eutrophication caused by excessive inputs of phosphorus $(\mathrm{P})$ and nitrogen $(\mathrm{N})$ is the most common impairment of surface waters in the United States (U.S. EPA 1990), with impairment measured as the area of surface water not suitable for designated uses such as drinking, irrigation, industry, recreation, or fishing. Eutrophication accounts for $\sim 50 \%$ of the impaired lake area and $60 \%$ of the impaired river reaches in the United States (U.S. EPA 1996), and is the most widespread pollution problem of U.S. estuaries (NRC 1993a). Other important causes of surface-water degradation are siltation caused by erosion from agriculture, logging and construction (which also contribute to eutrophication), acidification from atmospheric sources and mine drainage, contamination by toxins, introduction of exotic species, and hydrologic changes (NRC 1992).

Chemical inputs to rivers, lakes, and oceans are classified as point or nonpoint sources (Table 1). Pollutant discharges from point sources such as municipal sewage treatment plants tend to be continuous, with little variability over time. Often they can be monitored by measuring discharge and chemical concentrations periodically at a single place. Consequently, point sources are relatively simple to measure and regulate, and can often be controlled by treatment at the source. Nonpoint inputs can also be continuous, but are more often intermittent and linked to seasonal agricultural activity or irregular events, such as heavy precipitation or major construction. Nonpoint inputs often derive from extensive areas of land and are transported overland, underground, or through the atmosphere to receiving waters. Consequently, nonpoint sources are difficult to measure and regulate. Control of nonpoint pollution centers on land management practices and control of release of pollutants to the atmosphere, and may affect the daily activities of millions of people.

Nonpoint inputs are the major source of water pol-
TABLE 1. Characteristics of point and nonpoint sources of chemical inputs to receiving waters recognized by statutes of the United States (modified from Novotny and Olem 1994).

\section{Point sources}

Wastewater effluent (municipal and industrial)

Runoff and leachate from waste disposal sites

Runoff and infiltration from animal feedlots

Runoff from mines, oil fields, unsewered industrial sites

Storm sewer outfalls from cities with a population $>100000$

Overflows of combined storm and sanitary sewers

Runoff from construction sites $>2$ ha

Nonpoint sources

Runoff from agriculture (including return flow from irrigated agriculture)

Runoff from pasture and range

Urban runoff from unsewered areas and sewered areas with a population $<100000$

Septic tank leachate and runoff from failed septic systems

Runoff from construction sites $<2$ ha

Runoff from abandoned mines

Atmospheric deposition over a water surface

Activities on land that generate contaminants, such as logging, wetland conversion, construction, and development of land or waterways

lution in the United States (U.S. EPA 1990, 1996). The National Water Quality Inventory stated that "the more we look, the more we find" (U.S. EPA 1988). For example, $72-82 \%$ of eutrophic lakes would require control of nonpoint phosphorus inputs to meet water quality standards, even if point inputs were reduced to zero (Gakstatter et al. 1978).

In many cases, point sources of water pollution have been reduced, owing to their relative ease of identification and control. Point sources are still substantial in some parts of the world, and may increase with future expansion of urban areas and aquaculture. This report focuses on nonpoint sources, not because point sources are unimportant, but because nonpoint inputs are often overlooked. In addition, (1) restoration of most eutrophic waters requires the reduction of nonpoint inputs of $\mathrm{P}$ and $\mathrm{N}$; (2) we have a sound scientific understanding of the causes of nonpoint nutrient pollution and, in many cases, we have the technical knowledge needed to decrease nonpoint pollution to levels compatible with water quality standards; and (3) the most important barriers to control of nonpoint nutrient pollution appear to be social, political, and institutional. We hope that our summary of the scientific basis of the problem will inform and support the debate about solutions.

\section{Why Is Nonpoint P And N Pollution A CONCERN? \\ Eutrophication}

Scope and causes.-Eutrophication, caused by excessive inputs of $\mathrm{P}$ and $\mathrm{N}$, is a common and growing problem in lakes, rivers, estuaries, and coastal oceans (Smith 1998). Freshwater eutrophication has been a growing problem for decades (OECD 1982, NRC 1992). Both $P$ and $N$ supplies contribute to freshwater 
TABLE 2. Adverse effects on lakes, reservoirs, rivers, and coastal oceans caused by eutrophication (modified from Smith 1998)

Increased biomass of phytoplankton

Shifts in phytoplankton to bloom-forming species that may be toxic or inedible

Increases in blooms of gelatinous zooplankton (in marine environments)

Increased biomass of benthic and epiphytic algae

Changes in macrophyte species composition and biomass

Death of coral reefs and loss of coral reef communities

Decreases in water transparency

Taste, odor, and water treatment problems

Oxygen depletion

Increased incidence of fish kills

Loss of desirable fish species

Reductions in harvestable fish and shellfish

Decreases in perceived esthetic value of the water body

eutrophication (OECD 1982). For many lakes, excessive P inputs are the primary cause (Schindler 1977).

Eutrophication is also widespread and rapidly expanding in estuaries and coastal seas of the developed world (NRC 1993a, Nixon 1995). For most temperate estuaries and coastal ecosystems, $\mathrm{N}$ is the element most limiting to primary production and most responsible for eutrophication (Howarth 1988, NRC 1993a, Howarth et al. 1996, Nixon et al. 1996). Although $\mathrm{N}$ is the major factor in eutrophication of most estuaries and coastal seas, $\mathrm{P}$ is also an essential element that contributes to coastal eutrophication. It is, in fact, the dominant control of primary production in some coastal ecosystems.

Consequences.-Eutrophication has many negative effects on aquatic ecosystems (Table 2). Perhaps the most obvious consequence is the increased growth of algae and aquatic weeds that interfere with use of the water for fisheries, recreation, industry, agriculture, and drinking. Oxygen shortages caused by senescence and decomposition of nuisance plants cause fish kills. Eutrophication causes the loss of habitats, including aquatic plant beds in fresh and marine waters and coral reefs of tropical coasts (NRC 1993a, Jeppesen et al. 1998). Eutrophication is a factor in the loss of aquatic biodiversity (Seehausen et al. 1997).

Explosive growths of nuisance algae are among the most pernicious effects of eutrophication (Anderson and Garrison 1997). These algae are harmful to livestock, humans, and other organisms. In marine ecosystems, algal blooms (red or brown tides) cause widespread problems by releasing toxins and by causing anoxia when oxygen is consumed as dead algae decompose. The incidence of harmful algal blooms in coastal oceans has increased in recent years (Hallegraef 1993). The increase is linked to coastal eutrophication and other factors, such as changes in marine food webs that may reduce grazing or increase nutrient recycling. The blooms have severe negative impacts on aquaculture and shellfisheries (Shumway 1990). They cause shellfish poisoning in humans and have caused signif-
TABLE 3. Nitrogen and phosphorus discharges to surface waters (in $10^{3} \mathrm{Mg} / \mathrm{yr}$ ) from nonpoint and point sources in the United States.

\begin{tabular}{lcc}
\hline \hline \multicolumn{1}{c}{ Source } & Nitrogen & Phosphorus \\
\hline Nonpoint sources & 3204 & 615 \\
Croplands & 292 & 95 \\
Pastures & 778 & 242 \\
Rangelands & 1035 & 495 \\
Forests & 659 & 170 \\
Other rural lands & 695 & 68 \\
Other nonpoint sources & 6663 & 1658 \\
Total & 1495 & 330 \\
Total point sources & 8158 & 2015 \\
Total discharge (nonpoint + point) & $82 \%$ & $84 \%$ \\
Nonpoint as percentage of total & & \\
\hline
\end{tabular}

Note: Data are modified from Havens and Steinman (1995) and Gianessi et al. (1986).

icant mortality in marine mammals (Anderson 1994). A newly discovered toxic dinoflagellate has been associated with mortality of finfish on the U.S. Atlantic coast (Burkholder et al. 1992). The highly toxic, volatile chemical produced by this alga can cause longterm neurological damage to people who come in contact with it.

In freshwater, blooms of cyanobacteria (blue-green algae) are a prominent symptom of eutrophication (Kotak et al. 1993, McComb and Davis 1993, Smith 1998). These blooms contribute to a wide range of water-related problems including summer fish kills, foul odors, unpalatability of drinking water, and formation of trihalomethane during water chlorination in treatment plants (Palmstrom et al. 1988, Kotak et al. 1994). Water-soluble neuro- and hepatotoxins, released when cyanobacterial blooms die or are ingested, can kill livestock and may pose a serious health hazard to humans (Lawton and Codd 1991, Martin and Cooke 1994).

Contribution of nonpoint pollution.-Nonpoint sources are now the dominant inputs of $\mathrm{P}$ and $\mathrm{N}$ to most U.S. surface waters (Table 3). Nonpoint inputs of $P$ cause eutrophication of a large area of lakes and reservoirs in the United States (U.S. EPA 1990, 1996, NRC 1992). Nonpoint sources are also the dominant source of $\mathrm{P}$ and $\mathrm{N}$ to most reaches of U.S. rivers (Newman 1995), but point sources still contribute $>50 \%$ of the $\mathrm{P}$ and $\mathrm{N}$ reaching rivers from urbanized areas. Nonpoint $\mathrm{N}$ sources are responsible for $>90 \%$ of the $\mathrm{N}$ inputs to over one-half of the 86 rivers studied. Nonpoint $\mathrm{P}$ sources contributed $>90 \%$ of the $\mathrm{P}$ in one-third of these rivers (Newman 1995).

For many estuaries and coastal seas, nonpoint sources are the dominant $\mathrm{N}$ inputs (Nixon and Pilson 1983, NRC 1993a). Considering the entire coastline of the North Atlantic Ocean, nonpoint sources of $\mathrm{N}$ are $\sim$ ninefold greater than are inputs from wastewater treatment plants (Howarth et al. 1996). In some coastal areas, however, $\mathrm{N}$ inputs come primarily from wastewater treatment plants. Although nonpoint inputs of $\mathrm{P}$ are often significant, point source inputs of $\mathrm{P}$ are high 


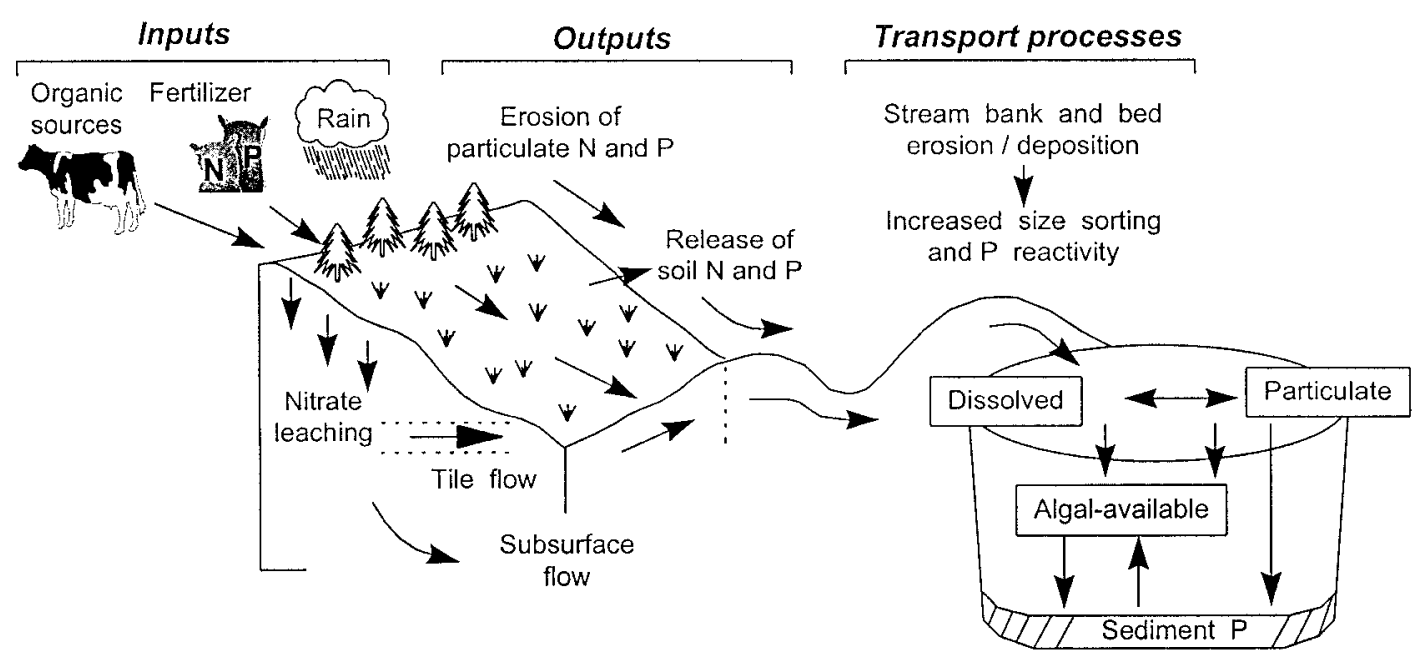

FIG. 1. Inputs, outputs, and processes of transport of $\mathrm{P}$ and $\mathrm{N}$ from agricultural land.

in many marine environments (van der Leeden et al. 1990).

Remediation.-Reversal of eutrophication requires the reduction of $\mathrm{P}$ and $\mathrm{N}$ inputs (NRC 1992). Recovery can sometimes be accelerated by combining input controls with other management methods (Sas 1989, NRC 1992, Cooke et al. 1993). Active intervention may be necessary, because the eutrophic state is relatively stable in lakes (Jeppesen et al. 1991, NRC 1992, Carpenter and Cottingham 1997). Some mechanisms that stabilize eutrophic conditions are effective internal recycling of $\mathrm{P}$, loss of rooted aquatic plants leading to destabilization of sediments, and changes in the food web that reduce grazing of nuisance algae (Carpenter and Cottingham 1997). Less is known about the stability of eutrophication in estuaries and coastal oceans, but the eutrophic state may be less stable because nutrients may be diluted and flushed away rapidly in open, wellmixed coastal oceans. However, in relatively confined, shallow marine waters such as the Baltic Sea, nutrients may be trapped and eutrophication may be as persistent as it is in lakes (Jansson 1995).

\section{Direct health effects}

Phosphorus in water is not considered to be directly toxic to humans and animals (Amdur et al. 1991). Because of this, no drinking water standards have been established for P (U.S. EPA 1990). Any toxicity caused by $\mathrm{P}$ in freshwaters is indirect. The proximal cause is toxic algal blooms or anoxic conditions stimulated by $\mathrm{P}$ pollution.

Nitrate pollution, in contrast, poses a direct health threat to humans and other mammals. $\mathrm{NO}_{3}$ in water is toxic at high concentrations and has been linked to methemoglobinemia in infants and toxic effects on livestock (Sandstedt 1990, Amdur et al. 1991). The EPA has established a maximum contaminant level for $\mathrm{NO}_{3}-\mathrm{N}$ in drinking water of $10 \mathrm{mg} / \mathrm{L}(45 \mathrm{mg} \mathrm{NO} / / \mathrm{L})$ to protect babies under 3-6 mo of age. This age group is most sensitive because bacteria that live in an infant's digestive tract can reduce $\mathrm{NO}_{3}$ to nitrite, causing conversion of hemoglobin into methemoglobin, which interferes with the oxygen-carrying ability of blood (Amdur et al. 1991). Nitrate can also be toxic to livestock if reduced to nitrite, which causes methemoglobinemia and abortions in cattle. $\mathrm{NO}_{3}-\mathrm{N}$ levels of $40-100 \mathrm{mg} / \mathrm{L}$ in drinking water are considered risky unless the feed is low in $\mathrm{NO}_{3}$ and fortified with vitamin $\mathrm{A}$ (Sandstedt 1990).

\section{What Are the Sources of Nonpoint Pollution?}

Nonpoint $\mathrm{P}$ and $\mathrm{N}$ pollution is caused primarily by agricultural and urban activities (Novotny and Olem 1994, Sharpley et al. 1994). Atmospheric deposition from diverse sources can add significant amounts of $\mathrm{N}$ to surface waters (Howarth et al. 1996). Agriculture is the predominant source of nonpoint nutrient pollution in the United States (NRC 1992, U.S. EPA 1996).

\section{Agriculture}

On the world's agricultural lands, nutrient transport by farming systems has overwhelmed natural nutrient cycles (Fig. 1). Globally, more nutrients are added as fertilizers than are removed as produce. Fertilizers are moved from areas of manufacture to areas of crop production. They are partly incorporated into crops, which are then moved to localized areas of human consumption and livestock production. Thus, there is a net transport of $\mathrm{P}$ and $\mathrm{N}$ from sites of fertilizer manufacture to sites of fertilizer deposition and manure production (Beaton et al. 1995). This flux creates a nutrient surplus on agricultural lands, the underlying cause of nonpoint pollution from agriculture.

Fertilizer.-Phosphorus is accumulating in the world's agricultural soils. Between 1950 and 1995, $\sim 600 \times 10^{6} \mathrm{Mg}$ of fertilizer P were applied to Earth's 
TABLE 4. Phosphorus balance and efficiency of plant and animal uptake of P for the United States (N.R.C. 1993b) and several European countries (Isermann 1991).

\begin{tabular}{|c|c|c|c|c|c|c|c|c|c|}
\hline \multirow[b]{2}{*}{ Nation } & \multirow{2}{*}{$\begin{array}{c}\text { Area in } \\
\text { agriculture } \\
\left(10^{6} \mathrm{ha}\right)\end{array}$} & \multicolumn{2}{|c|}{$\begin{array}{c}\text { P input } \\
\left(\mathrm{kg} \cdot \mathrm{ha}^{-1} \cdot \mathrm{yr}^{-1}\right)\end{array}$} & \multicolumn{2}{|c|}{$\begin{array}{c}\mathrm{P} \text { output } \\
\left(\mathrm{kg} \cdot \mathrm{ha}^{-1} \cdot \mathrm{yr}^{-1}\right)\end{array}$} & \multirow{2}{*}{$\underset{\left(\mathrm{kg} \cdot \mathrm{ha}^{-1} \cdot \mathrm{yr}^{-1}\right)}{\mathrm{P} \text { surplus }}$} & \multicolumn{3}{|c|}{ Efficiency of uptake (\%) } \\
\hline & & Fertilizer & Feed & Animal & Plant & & Plant & Animal & Total \\
\hline East Germany & 6.2 & 25 & 6 & 3 & 1 & 27 & 59 & 10 & 11 \\
\hline West Germany & 12.0 & 27 & 10 & 10 & 3 & 24 & 76 & 34 & 35 \\
\hline Ireland & 5.7 & 11 & 1 & 3 & 1 & 8 & 72 & 22 & 30 \\
\hline Netherlands & 2.3 & 18 & 44 & 17 & 5 & 40 & 69 & 24 & 38 \\
\hline Switzerland & 1.1 & 22 & 11 & 6 & 4 & 23 & 91 & 18 & 28 \\
\hline United Kingdom & 18.5 & 9 & 3 & 2 & 1 & 9 & 55 & 18 & 25 \\
\hline United States & 394.7 & 39 & 5 & 13 & 5 & 26 & 56 & 15 & 33 \\
\hline
\end{tabular}

surface, primarily on croplands (Brown et al. 1997, FAO 1950-1995). During the same time period, $\sim 250$ $\times 10^{6} \mathrm{Mg}$ of $\mathrm{P}$ were removed from croplands through harvest (Beaton et al. 1995, Brown et al. 1997, FAO 1950-1995). Some of the harvested $\mathrm{P}\left(\sim 50 \times 10^{6} \mathrm{Mg}\right)$ was reapplied to cropland as animal manure (NRC $1993 b$ ). Thus, the net addition of $\mathrm{P}$ to croplands over this period was $\sim 400 \times 10^{6} \mathrm{Mg}$. This applied $\mathrm{P}$ may either remain in soils or be exported to surface waters by erosion or leaching. The majority of applied $\mathrm{P}$ remains on croplands, with only 3-20\% leaving by export to surface waters (Caraco 1995). It is likely, therefore, that $\sim 350 \times 10^{6} \mathrm{Mg}$ of $\mathrm{P}$ have accumulated in the world's croplands. The standing stock of $\mathrm{P}$ in the upper $10 \mathrm{~cm}$ of soil in the world's croplands is $\sim 1300 \mathrm{Mg}$ (Pierrou 1975). Therefore, the net addition of $350 \times$ $10^{6} \mathrm{Mg}$ between 1950 and 1995 would have increased the $\mathrm{P}$ content of agricultural soils by $\sim 25 \%$. In the United States and Europe, only $\sim 30 \%$ of the $\mathrm{P}$ input in fertilizers is output in produce, resulting in an average accumulation rate of $22 \mathrm{~kg} \cdot \mathrm{ha}^{-1} \cdot \mathrm{y}^{-1}$ for surplus $P$ (Table 4). At the watershed scale, excess inputs of $\mathrm{P}$ to agriculture relative to outputs in produce are closely linked to eutrophication of surface waters (Fluck et al. 1992).

Global industrial $\mathrm{N}$ fixation for fertilizers has increased steeply from nearly zero in the 1940s to $\sim 80$ $\times 10^{6} \mathrm{Mg} / \mathrm{yr}$ (Vitousek et al. 1997). In the United States and Europe, only $18 \%$ of the $\mathrm{N}$ input in fertilizer is removed from farms in produce, leaving behind, on average, $174 \mathrm{~kg} \cdot \mathrm{ha}^{-1} \cdot \mathrm{y}^{-1}$ of surplus $\mathrm{N}$ (Isermann 1991, NRC 1993b). This surplus may accumulate in soils, erode or leach to surface and ground waters, or enter the atmosphere (Vitousek et al. 1997). $\mathrm{N}$ is added to the atmosphere through volatilization of $\mathrm{NH}_{3}$ (Schlesinger and Hartley 1992) and microbial generation of $\mathrm{N}_{2} \mathrm{O}$ (Eichner 1990). $\mathrm{N}_{2} \mathrm{O}$ is a gas that contributes to global warming and can catalyze the destruction of ozone (Vitousek et al. 1997). Much of the N volatilized to the atmosphere is redeposited on land or water and eventually enters aquatic ecosystems (Howarth et al. 1996).

Manure.-Intensive animal production generally involves feeding large numbers of animals in small areas
(NRC 1993b). For example, only $4 \%$ of the cattle feedlots in the United States produce $84 \%$ of the cattle (NRC 1993b). These large concentrations of animals create enormous amounts of waste. Disposal problems are comparable to those for raw human sewage, but the regulatory standards for animal waste are generally far less stringent than those for human sewage.

Nutrients in manure can be recycled by applying the manure to cropland. However, manure yields from concentrated livestock operations often exceed the capacity of croplands to sequester the nutrients (NRC 1993b). At typical stocking rates for feedlots, an area of cropland $\sim 1000$ times greater than the feedlot area is required to distribute manure nutrients at levels similar to crop demand (NRC 1993b). This much land may not be available, so manure is applied to excess. These nutrients build up in soil, run off or infiltrate to water supplies, or (in the case of $\mathrm{N}$ ) can enter the atmosphere.

Transport to aquatic ecosystems. - Increased fluxes of $\mathrm{P}$ and $\mathrm{N}$ to surface waters have been measured after application of fertilizer or manure to farm land (Sharpley and Rekolainen 1996). Fertilizer P and $\mathrm{N}$ losses in runoff are generally $<5 \%$ of that applied. Manurial losses can be slightly higher (up to $20 \%$, if rainfall immediately follows application). These percentages underestimate the total $\mathrm{N}$ flux to aquatic ecosystems because they do not include infiltration and leaching, which ultimately carry $\mathrm{N}$ to ground and surface waters. $\mathrm{N}$ export from agricultural ecosystems to water, as a percentage of fertilizer inputs, ranges from $10 \%$ to $40 \%$ for loam and clay soils to $25 \%$ to $80 \%$ for sandy soils (Howarth et al. 1996). In general, flux rates of nutrients to water from fertilizer and manure are influenced by the rate, season, chemical form, and method of nutrient application; amount and timing of rainfall after application; and vegetative cover. The greater proportional losses of $\mathrm{P}$ and $\mathrm{N}$ from manure may result from higher $\mathrm{P}$ and $\mathrm{N}$ application rates and less flexibility in the timing of applications (Sharpley and Rekolainen 1996).

The amount of $\mathrm{P}$ lost to surface waters increases with the P content of the soil (Fig. 2). Relationships similar to those in Fig. 2 have been demonstrated for a diversity of soils (Sharpley et al. 1996). Fig. 2 shows losses of dissolved $\mathrm{P}$, but even more $\mathrm{P}$ is transported as particles. 

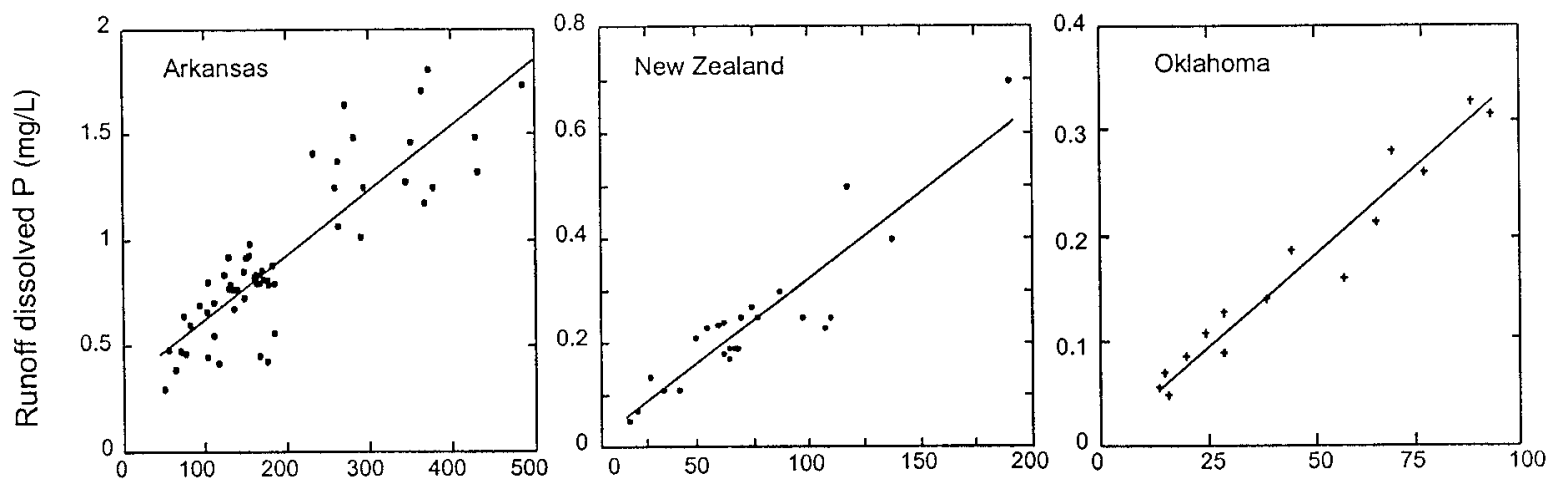

Mehlich-3 extractable soil P $(\mathrm{mg} / \mathrm{kg})$

FIG. 2. Effect of soil test $\mathrm{P}$ (Mehlich-3) on the dissolved $\mathrm{P}$ concentration of runoff from pasture catchments in Arkansas (fescue: $y=0.32+0.0031 x ; R^{2}=0.76$ ), New Zealand $\left(y=0.01+0.0033 x ; R^{2}=0.85\right.$ ), and Oklahoma (fescue: $y=0.02$ $\left.+0.0031 x ; R^{2}=0.88\right)$, modified from Sharpley et al. (1996).

In the long term, this particulate $\mathrm{P}$ can become available to the aquatic biota (NRC 1992, Sharpley et al. 1994).

In recent decades, $\mathrm{N}$ transport to the oceans has increased (Howarth et al. 1996). It is correlated with various indices of human activity in the watershed (Cole et al. 1993, Howarth et al. 1996, Vitousek et al. 1997). Similarly, P flux to the oceans in rivers is positively correlated with human population density (Caraco 1995). Globally, $P$ flux to coastal oceans has increased from an estimated pristine flux rate of $8 \times 10^{6}$ $\mathrm{Mg} / \mathrm{yr}$ to the current rate of $22 \times 10^{6} \mathrm{Mg} / \mathrm{yr}$ (Howarth et al. 1995). Of this increase, $\sim 30 \%$ is attributed to $\mathrm{P}$ enrichment of agricultural soils and the remainder to increasing rates of erosion.

\section{Urban runoff}

A significant amount of $\mathrm{P}$ and $\mathrm{N}$ enters surface waters from urban nonpoint sources, such as construction sites, runoff of lawn fertilizers and pet wastes, and inputs from unsewered developments. Urban runoff is the third most important cause of lake deterioration in the United States (U.S. EPA 1990), affecting 28\% of the lake area that does not meet water quality standards. Urban point sources of water pollution, such as sewage and industrial discharges, are also significant and often are managed intensively.

Construction sites are a critical area of concern for urban nonpoint pollution. Although construction sites may occupy a relatively small percentage of the land area, erosion rates for construction sites can be extremely high, so the total nonpoint pollution yield is large. Erosion rates from watersheds under development approach $50000 \mathrm{Mg} \cdot \mathrm{km}^{-2} \cdot \mathrm{yr}^{-1}$, compared to 1000-4000 Mg. $\mathrm{km}^{-2} \cdot \mathrm{yr}^{-1}$ for agriculture and $<100$ $\mathrm{Mg} \cdot \mathrm{km}^{-2} \cdot \mathrm{yr}^{-1}$ for undisturbed vegetation (Novotny and Olem 1994). This eroded material contributes to siltation of water bodies as well as to eutrophication (U.S. EPA 1990).

\section{Atmospheric deposition of $N$}

$\mathrm{N}$ deposited to aquatic ecosystems from the atmosphere has several origins, including gases released from agriculture and burning of fossil fuels (Vitousek et al. 1997). Combustion releases significant quantities of fixed $\mathrm{N}$ into the atmosphere, both from the oxidation of organic $\mathrm{N}$ stored in the fossil fuels and from the "fixation" of molecular $\mathrm{N}_{2}$ during high-temperature, high-pressure combustion. Currently, $\sim 20 \times 10^{6} \mathrm{Mg} /$ yr of fixed $\mathrm{N}$ are released globally from fossil fuel combustion (Galloway et al. 1995). This is only onefourth of the amount of $\mathrm{N}$ used in inorganic $\mathrm{N}$ fertilizer and perhaps one-seventh of the total amount of $\mathrm{N}$ fixed globally through human activity, including inorganic fertilizers and $\mathrm{N}$ fixation by agricultural crops (Vitousek et al. 1997). Nonetheless, $N$ from fossil fuel combustion may contribute substantially to the nonpoint pollution of surface waters.

In a comparative study of $\mathrm{N}$ fluxes from 33 rivers in the northeastern United States, Jaworski et al. (1997) found that the fluxes of both $\mathrm{NO}_{3}$ and total $\mathrm{N}$ in the rivers were correlated with the atmospheric deposition of oxidized $\mathrm{N}$ (which comes largely from fossil fuel combustion) onto the watersheds of these rivers (Fig. 3 ). For a small subset of these rivers, Jaworski et al. (1997) obtained historical data on $\mathrm{NO}_{3}$ concentrations from the early 1900 s to the present. Nitrate concentrations increased in all of the rivers over that time period. The increase in $\mathrm{NO}_{3}$ concentration over time was correlated with estimates for increased fossil fuel emissions of $\mathrm{N}$.

We have much to learn about the transport of atmospherically derived $\mathrm{N}$ from land to water. Clearly, the atmosphere can be a significant source of $\mathrm{N}$ to aquatic ecosystems and can make potentially large contributions to coastal eutrophication (Howarth et al. 1996). However, volatilization from agricultural land 


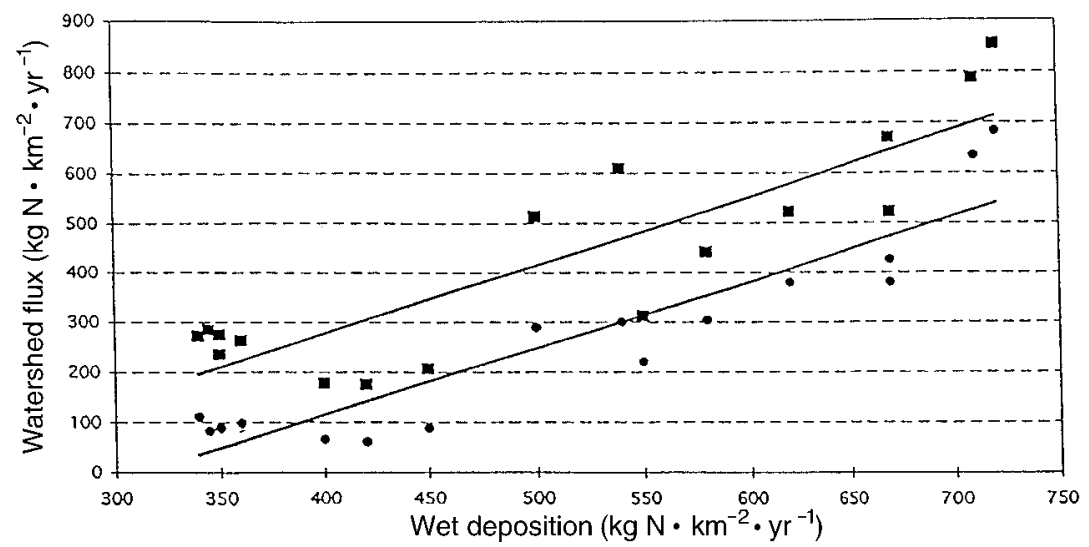

FIG. 3. Export of total $\mathrm{N}$ and $\mathrm{NO}_{3}-\mathrm{N}$ in 17 rivers vs. wet deposition of oxidized $\mathrm{N}$ onto their watersheds (modified from Jaworski et al. 1997). For total $\mathrm{N}$, the regression is $y=1.36 x-267.5 ; R^{2}=0.76$; for inorganic $\mathrm{N}, y=1.32 x-415.4 ; R^{2}$ $=0.86$.

is the source of a significant fraction of this $\mathrm{N}$ (Howarth et al. 1996, Vitousek et al. 1997).

\section{What Can Be Done about It?}

Unless current practices are changed, nonpoint pollution of surface waters will increase in the future. Some factors that drive this expectation are the substantial and growing accretion of $\mathrm{P}$ and $\mathrm{N}$ in agricultural ecosystems; a growing human population; the tendency for people to eat diets rich in meat; increasing livestock production; growth of urban areas, with associated development and erosion; and increased fixation of $\mathrm{N}$ by human activities such as the manufacturing of fertilizer and the burning of fossil fuels. Ironically, the increasing use of more efficient engines and turbines for burning fossil fuels has the inadvertent effect of increasing the fixation of $\mathrm{N}$.

However, this pessimistic forecast could prove to be incorrect, because there are a number of ways that nonpoint pollution can be reduced. Here, we offer a brief catalog, in no particular order.

\section{Landscape management}

Riparian (shoreline) vegetation can significantly reduce nonpoint nutrient flows to surface waters (Lowrance et al. 1985, Correll et al. 1992, Osborne and Kovacic 1993, Hill 1996). This vegetation also makes important contributions to fish and wildlife habitat and regional biodiversity. Interest in the use of riparian vegetation for nonpoint pollution control has grown rapidly in recent years, as evidenced by more than 500 publications on the subject (Correll 1997 and www.serc.si.edu).

Wetlands, lakes, and rivers are sites of denitrification (conversion of the nutrient $\mathrm{NO}_{3}$ to atmospheric $\mathrm{N}_{2}$ ) that decrease the flow of $\mathrm{N}$ to downstream ecosystems (Jansson et al. 1994). Restoration of wetlands and floodplains (NRC 1992) is likely to increase denitrification at a landscape scale, thereby reducing $\mathrm{N}$ pol- lution of aquatic systems to some extent. Wetland restoration may be the most cost-effective method of decreasing nonpoint N pollution (Gren 1995).

\section{Agricultural $P$ and $N$ management}

The ultimate causes of nonpoint pollution from agricultural lands are excessive fertilizer use and highdensity livestock operations. There are direct solutions. Fertilizer application can be reduced to match crop needs. Wastes from high-density livestock operations can be managed as a point source of pollution. Nutrients in manure can be used as fertilizer, or nutrients can be removed (as in sewage treatment) before wastes are discharged to surface waters. Work to implement these solutions now focuses on establishing threshold levels of soil nutrients that threaten water quality, delineation of intensive sources of pollutants, and controlling both nutrient sources and transport.

Thresholds.-Threshold levels of soil nutrients that create unacceptable threats to water quality are needed to provide a firm basis for regulations that protect aquatic resources. Defining thresholds has been controversial, in part because data are insufficient. Unfortunately, the database relating soil nutrient concentrations to runoff is limited to a few soils and crops, making it difficult to extrapolate these data to other regions. Because costs of manure management are significant, those most affected by thresholds have vigorously challenged their scientific basis. A stronger scientific foundation can, and should, be developed for soil nutrient thresholds so that scientifically based standards can be promulgated and defended.

Source area delineation.-Typically, $>90 \%$ of the $\mathrm{P}$ export from watersheds derives from $<10 \%$ of the land area during a few large storms (Pionke et al. 1997). Regulation and management of $\mathrm{P}$ runoff can most effectively focus on lands that combine high soil $\mathrm{P}$ concentrations with high erosion and surface runoff characteristics. 
Source management.- $\mathrm{N}$ and $\mathrm{P}$ runoff can be greatly reduced if nutrients are applied at rates that match their uptake by crops, and if fertilizers are applied when crops are growing rapidly (Sharpley et al. 1994). Also, dietary $\mathrm{P}$ inputs to livestock can be matched to the animals' requirements to decrease the amounts of $\mathrm{P}$ excreted on to land (Wadman et al. 1987, Morse et al. 1992, Mahan and Howes 1995). Source management can significantly reduce concentrations of $\mathrm{P}$ in the runoff entering aquatic ecosystems. Aggressive treatment of dairy wastes in Florida, for example, reduced total $\mathrm{P}$ concentrations in surface water by $62-87 \%$ (Havens et al. 1996).

Transport management.-Transport of $\mathrm{P}$ and $\mathrm{N}$ to surface waters by erosion and runoff may be reduced by riparian zones, buffer strips, conservation tillage, terracing, contour tillage, cover crops, and retention ponds (Osborne and Kovacic 1993, Sharpley et al. 1994, Sharpley and Smith 1994, Correll 1997). Vegetated buffer strips in riparian zones, for example, reduce $\mathrm{P}$ transport to streams by $50-85 \%$ (Osborne and Kovacik 1993). Without concurrent reductions in nutrient sources to soils, however, soil nutrients will continue to accumulate.

\section{Control of urban runoff}

Control of urban nonpoint pollution is a well-developed branch of civil engineering, with an extensive and sophisticated literature (Novotny and Olem 1994). Optimization of sewer systems is a key goal. Other approaches used to varying degrees include the creation of retention ponds, wetlands, and greenways as an integrated component of urban stormwater management systems; litter control and street sweeping; reduction of impervious areas; and reduction of erosion, especially from construction sites.

\section{Atmospheric deposition}

Atmospheric deposition of $\mathrm{N}$ can be reduced by more efficient use of fertilizers and improved handling of animal wastes. Thus, steps needed to reduce surface transport of agricultural $\mathrm{N}$ will also reduce atmospheric transport. Reductions in fossil fuel combustion and improved interception of $\mathrm{NO}_{3}$ from fossil fuel combustion will also reduce atmospheric deposition of N (Vitousek et al. 1997).

\section{CONCLUSION}

A sound fundamental understanding of the processes that cause nonpoint pollution and eutrophication exists. At regional and global scales, the causes and consequences of nonpoint pollution are clear. There is need for site-specific analyses, and the capacity for such analyses is well developed and improving. The most critical need in reducing nonpoint pollution and mitigating eutrophication may be creative institutional mechanisms that match scientific understanding with social realities (Gunderson et al. 1995). Although science alone cannot solve the problem, our evaluation of the literature suggests that the necessary scientific understanding is well developed and could be readily mobilized in the search for solutions.

\section{ACKNOWLEDGMENTS}

We thank E. M. Bennett, L. Pitelka, T. Reed, G. D. Tilman, and anonymous referees for helpful comments on the manuscript. This report was supported by Pew Fellowships to S. R. Carpenter and G. D. Tilman and the NTL-LTER site.

\section{Literature Cited}

Amdur, M. O., J. Dull, and E. D. Klassen, editors. 1991. Casarett and Doull's toxicology. Fourth edition. Pergamon Press, New York, New York, USA.

Anderson, D. M. 1994. Red tides. Scientific American 271: $62-68$.

Anderson, D. M., and D. J. Garrison, editors. 1997. The ecology and oceanography of harmful algal blooms. Limnology and Oceanography 42:1009-1305.

Beaton, J. D., T. L. Roberts, E. H. Halstead, and L. E. Cowell. 1995. Global transfers of $P$ in fertilizer materials and agricultural commodities. Pages 7-26 in H. Tiessen, editor. Phosphorus in the global environment: transfers, cycles and management. John Wiley, New York, New York, USA.

Brown, L. R., M. Renner, and C. Flavin. 1997. Vital signs: the environmental signs that are shaping our future. World Watch Institute, Washington, D.C., USA.

Burkholder, J. M., E. J. Noga, C. W. Hobbs, H. B. Glasgow, Jr., and S. A. Smith. 1992. New "phantom" dinoflagellate is the causative agent of major estuarine fish kills. Nature 358:407-410.

Caraco, N. F. 1995. Influence of human populations on P transfers to aquatic systems: a regional scale study using large rivers. Pages 235-244 in H. Tiessen, editor. Phosphorus in the global environment. John Wiley, New York, New York, USA.

Carpenter, S. R., and K. L. Cottingham. 1997. Resilience and restoration of lakes. Conservation Ecology 1:2. Available on the Internet. URL: http://www.consecol.org/vol1/ iss $1 /$ art2

Cole, J. J., B. L. Peierls, N. F. Caraco, and M. L. Pace. 1993. Nitrogen loading of rivers as a human-driven process. Pages 141-157 in M. J. McDonnell and S. T. A. Pickett, editors. Humans as components of ecosystems. SpringerVerlag, New York, New York, USA.

Cooke, G. D., E. B. Welch, S. A. Peterson, and P. R. Newroth. 1993. Restoration and management of lakes and reservoirs. Lewis, Boca Raton, Florida, USA.

Correll, D. L. 1997. Buffer zones and water quality protection: general principles. Pages 7-20 in N. E. Haycock, T. P. Burt, K. W. T. Goulding, and G. Pinay, editors. Buffer zones: their processes and potential in water protection. Quest Environmental, Harpendon, UK.

Correll, D. L., T. E. Jordan, and D. E. Weller 1992. Nutrient flux in a landscape: effects of coastal land use and terrestrial community mosaic on nutrient transport to coastal waters. Estuaries 15:431-442.

Eichner, M. J. 1990. Nitrous oxide emissions from fertilized soils: summary of the available data. Journal of Environmental Quality 19:272-280.

FAO (Food and Agriculture Organization). 1950-1995. Fertilizer Yearbook. FAO Statistics Series, Rome, Italy.

FAO (Food and Agriculture Organization). 1950-1995. Production Yearbook. FAO Statistics Series, Rome, Italy.

Fluck, R. C., C. Fonyo, and E. Flaig. 1992. Land-based phosphorus balances for Lake Okeechobee, Florida drainage basins. Applied Engineering in Agriculture 8:813-820. 
Gakstatter, J. H., A. F. Bartsch, and C. A. Callahan. 1978 The impact of broadly applied effluent phosphorus standards on eutrophication control. Water Resources Research 14: $1155-1158$

Galloway, J. N., W. H. Schlesinger, H. Levy, A. Michaels, and J. L. Schnoor. 1995. Nitrogen fixation: atmospheric enhancement-environmental response. Global Biogeochemical Cycles 9:235-252.

Gianessi, L. P., H. M. Peskin, P. Crosson, and C. Puffer. 1986. Non-point source pollution: are cropland controls the answer? U.S. Department of Agriculture and U.S. Environmental Protection Agency, Washington, D.C., USA.

Gren, I. M. 1995. The value of investing in wetlands for nitrogen abatement. European Review of Agricultural Economics 22:157-172.

Gunderson, L. A., C. S. Holling, and S. S. Light, editors 1995. Barriers and bridges to the renewal of ecosystems and institutions. Columbia University Press, New York, New York, USA.

Hallegraeff, G. M. 1993. A review of harmful algal blooms and their apparent global increase. Phycologia 32:79-99.

Havens, K. E., E. G. Flaig, R. T. James, S. Lostal, and D. Muszick. 1996. Environmental auditing: results of a program to control phosphorus discharges from dairy operations in south-central Florida, U.S.A. Environmental Management 20:585-593.

Havens, K. E., and A. D. Steinman. 1995. Aquatic systems. Pages 121-151 in J. E. Rechcigl, editor. Soil amendments: impacts on biotic systems. Lewis, Boca Raton, Florida, USA.

Hill, A. R. 1996. Nitrate removal in stream riparian zones. Journal of Environmental Quality 25:743-755.

Howarth, R. W. 1988. Nutrient limitation of net primary production in marine ecosystems. Annual Review of Ecology and Systematics 19:898-110.

Howarth, R. W., G. Billen, D. Swaney, A. Townsend, N. Jaworski, K. Lajtha, J. A. Downing, R. Elmgren, N. Caraco, T. Jordan, F. Berendse, J. Freney, V. Kudeyarov, P. Murdoch, and Zhu Zhao-liang. 1996. Regional nitrogen budgets and riverine inputs of $\mathrm{N}$ and $\mathrm{P}$ for the drainages to the North Atlantic Ocean: natural and human influences. Biogeochemistry 35:75-139.

Howarth, R. W., H. S. Jenson, R. Marino, and H. Postma. 1995. Transport to and processing of $\mathrm{P}$ in near-shore and oceanic waters. Pages 323-345 in H. Tiessen, editor. Phosphorus in the global environment. John Wiley, New York, New York, USA.

Isermann, K. 1991. Share of agriculture in nitrogen and phosphorus emissions into the surface waters of Western Europe against the background of their eutrophication. Fertilizer Research 26:253-269.

Jansson, A. M., R. Andersson, H. Berggren, and L. Leonardson. 1994. Wetlands and lakes as nitrogen traps. Ambio 23:320-325.

Jansson, B.-O. 1995. The Baltic: the sea of surprises. Pages 292-372 in L. H. Gunderson, C. S. Holling, and S. S. Light, editors. Barriers and bridges to the renewal of ecosystems and institutions. Columbia University Press, New York, New York, USA.

Jaworski, N. A., R. W. Howarth, and L. J. Hetling. 1997. Atmospheric deposition of nitrogen oxides onto the landscape contributes to coastal eutrophication in the northeast Unites States. Environmental Science and Technology 31: 1995-2004.

Jeppesen, E., P. Kristensen, J. Jensen, M. Sondergaard, E. Mortensen, and T. Lauridsen. 1991. Recovery resilience following a reduction in external phosphorus loading of shallow eutrophic Danish lakes: duration, regulating factors and methods for overcoming resilience. Istituto Italiano di Idrobiologie 48:127-148.
Jeppesen, E., Ma. Sondergaard, Mo. Sondergaard, and K. Christofferson, editors. 1998. The structuring role of submerged macrophytes in lakes. Springer-Verlag, New York, New York, USA.

Kotak, B. G., S. L. Kenefick, D. L. Fritz, C. G. Rousseaux, E. E. Prepas, and S. E. Hrudey. 1993. Occurrence and toxicological evaluation of cyanobacterial toxins in Alberta lakes and farm dugouts. Water Research 27:495-506.

Kotak, B. G., E. E. Prepas, and S. E. Hrudey. 1994. Blue green algal toxins in drinking water supplies: research in Alberta. Lake Line 14:37-40.

Lawton, L. A., and G. A. Codd. 1991. Cyanobacterial (bluegreen algae) toxins and their significance in UK and European waters. Journal of the Institute of Water and Environment Management 5:460-465.

Lowrance, R., R. Leonard, and J. Sheridan 1985. Managing riparian ecosystems to control nonpoint pollution. Journal of Soil and Water Conservation 40:87-97.

Mahan, D. C., and D. Howes. 1995. Environmental aspects with particular emphasis on phosphorus, selenium, and chromium in livestock feed. Pages 75-91 in 13th Annual Pacific Northwest Animal Nutrition Conference, Portland, Oregon, USA.

Martin, A., and G. D. Cooke. 1994. Health risks in eutrophic water supplies. Lake Line 14:24-26.

McComb, A. J., and J. A. Davis. 1993. Eutrophic waters of southwestern Australia. Fertilizer Research 36:104-114.

Morse, D., H. H. Head, C. J. Wilcox, H. H. van Hern, C. D. Hissem, and B. Harris, Jr. 1992. Effects of concentration of dietary phosphorus on amount and route of excretion. Journal of Dairy Science 75:3039-3045.

Newman, A. 1995. Water pollution point sources still significant in urban areas. Environmental Science and Technology 29:114.

Nixon, S. W. 1995. Coastal marine eutrophication: a definition, causes, and future concerns. Ophelia 41:119-219.

Nixon, S. W., and M. E. Q. Pilson. 1983. Nitrogen in estuarine and coastal marine ecosystems. In E. J. Carpenter and D. G. Capone, editors. Nitrogen in the marine environment. Academic Press, New York, New York, USA.

Nixon, S. W., J. W. Ammerman, L. P. Atkinson, V. M. Berounsky, G. Bilen, W. C. Boicourt, W. R. Boynton, T. M. Church, D. M. DiToro, R. Elmgren, J. Garber, A. E. Giblin, R. A. Jahnke, N. J. P. Owens, M. E. Q. Pilson, and S. P. Seitzinger. 1996. The fate of nitrogen and phosphorus at the land-sea margin of the North Atlantic Ocean. Biogeochemistry 35:141-180.

Novotny, V., and H. Olem. 1994. Water quality: prevention, identification and management of diffuse pollution. Van Nostrand Reinhold, New York, New York, USA.

NRC (National Research Council). 1992. Restoration of aquatic ecosystems: science, technology and public Policy. National Academy Press, Washington, D.C., USA.

. 1993a. Managing wastewater in coastal urban areas. National Academy Press, Washington, D.C., USA.

- 1993b. Soil and water quality: an agenda for agriculture. National Academy Press, Washington, D.C., USA. OECD (Organization for Economic Cooperation and Development). 1982. Eutrophication of waters: monitoring, assessment and control. Organisation for Economic and Cooperative Development, Paris, France.

Osborne, L. L., and D. A. Kovacic. 1993. Riparian vegetated buffer strips in water-quality restoration and stream management. Freshwater Biology 29:243-258.

Palmstrom, N. S., R. E. Carlson, and G. D. Cooke. 1988. Potential links between eutrophication and formation of carcinogens in drinking water. Lake and Reservoir Management 4:1-15.

Pierrou, U. 1975. The global phosphorus cycle. Ecological Bulletin (Stockholm) 22:75-88. 
Pionke, H. B., W. J. Gburek, A. N. Sharpley, and J. A. Zollweg. 1997. Hydrologic and chemical controls on phosphorus loss from catchments. Pages 2-9 in H. Tunney, editor. Phosphorus loss to water from agriculture. CAB International, Cambridge, UK.

Postel, S. L. 1997. Last oasis. Second edition. Island Press, Washington, D.C., USA.

Postel, S. L., and S. R. Carpenter. 1997. Freshwater ecosystem services. Pages 195-214 in G. C. Daily, editor. Nature's Services. Island Press, Washington, D.C., USA.

Postel, S. L., G. C. Daily, and P. R. Ehrlich. 1996. Human appropriation of renewable fresh water. Science 271:785788 .

Sandstedt, C. A. 1990. Nitrates: sources and their effects upon humans and livestock. American University, Washington, D.C., USA.

Sas, H. 1989. Lake restoration by reduction of nutrient loading: expectations, experiences, extrapolations. Academia Verlag, Richarz, St. Augustin, Germany.

Schindler, D. W. 1977. Evolution of phosphorus limitation in lakes. Science 195:260-262.

Schlesinger, W. H., and A. E. Hartley. 1992. A global budget for atmospheric $\mathrm{NH}_{3}$. Biogeochemistry 15:191-211.

Seehausen, O., J. J. M. van Alphen, and F. Witte. 1997. Cichlid fish diversity threatened by eutrophication that curbs sexual selection. Science 277:1808-1811.

Sharpley, A. N., S. C. Chapra, R. Wedepohl, J. T. Sims, T. C. Daniel, and K. R. Reddy. 1994. Managing agricultural phosphorus for protection of surface waters: issues and options. Journal of Environmental Quality 23:437-451.

Sharpley, A. N., T. C. Daniel, J. T. Sims, and D. H. Pote. 1996. Determining environmentally sound soil phosphorus levels. Journal of Soil and Water Conservation 51:160166.

Sharpley, A. N. and S. Rekolainen. 1996. Phosphorus in agriculture and its environmental implications. Pages 1-54 in H. Tunney, O. T. Carton, P. C. Brookes, and A. E. Johnson, editors. Phosphorus losses from soil to water. CAB International, Cambridge, UK.

Sharpley, A. N., and S. J. Smith. 1994. Wheat tillage and water quality in the Southern Plains. Soil Tillage Research 30:33-48.

Shumway, S. E. 1990. A review of the effects of algal blooms on shellfish and aquaculture. Journal of the World Aquaculture Society 21:65-104.

Smith, V. H. 1998. Cultural eutrophication of inland, estuarine, and costal waters. In M. L. Pace and P. M. Groffman, editors. Successes, limitations, and frontiers in ecosystem science. Springer-Verlag, New York, New York, USA.

U.S. EPA (U.S. Environmental Protection Agency). 1988. Quality criteria for water. EPA 440/5-86-001. USEPA, Office of Water Regulations and Standards. U.S. Government Printing Office (PB81-226759), Washington, D.C., USA.

. 1990. National water quality inventory. 1988 Report to Congress. Office of Water. U.S. Government Printing Office, Washington, D.C., USA.

1996. Environmental indicators of water quality in the United States. EPA 841-R-96-002. USEPA, Office of Water (4503F), U.S. Government Printing Office, Washington, D.C., USA.

van der Leeden, F., F. L. Troise, and D. K. Todd. 1990. The water encyclopedia. Lewis, Chelsea, Michigan.

Vitousek, P. M., J. Aber, R. W. Howarth, G. E. Likens, P. A. Matson, D. W. Schindler, W. H. Schlesinger, and G. D. Tilman. 1997. Human alteration of the global nitrogen cycle: Causes and consequences. Ecological Applications 7:737-750.

Wadman, W. P., C. M. J. Sluijsmans, and L. C. N. De La Lande Cremer. 1987. Value of animal manures: changes in perception. Pages 1-16 in H. J. Van der Meer, R. J. Unwin, T. A. van Dijk, and G. C. Ennik, editors. Animal manure on grassland and fodder crops. Martinus Nijhoff, Dordrecht, The Netherlands. 